\title{
Peta Digital Dusun Pagersari, Mranggen, Srumbung, Magelang Berbasis Aplikasi CarryMap
}

\author{
Digital Map of Pagersari Hamlet, Mranggen, Srumbung, Magelang Based on CarryMap \\ Application
}

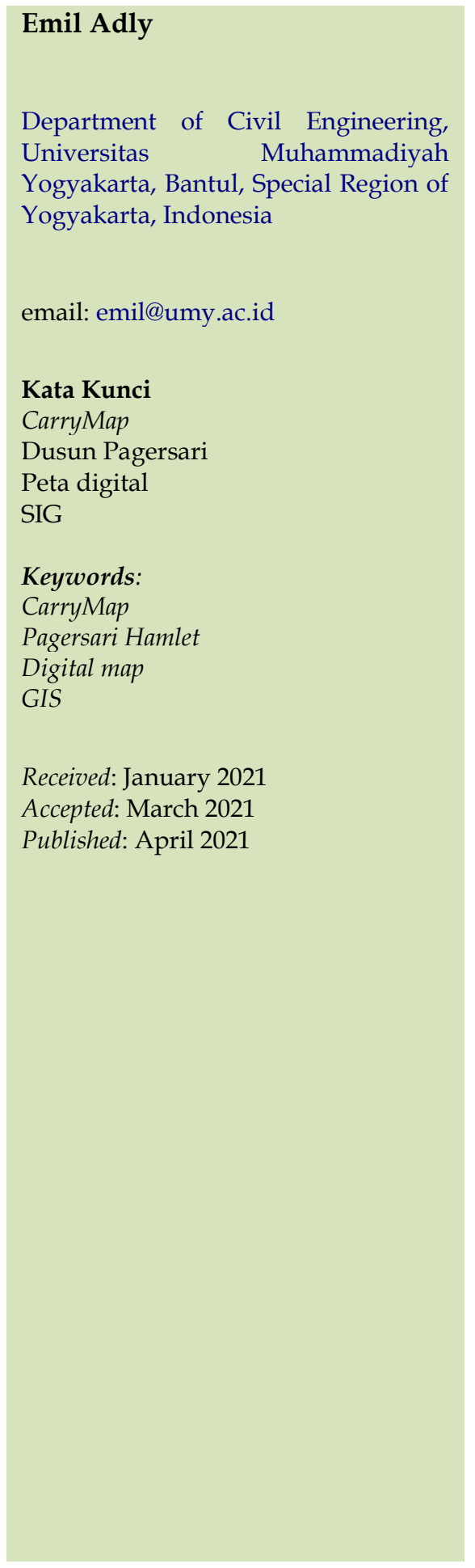

\begin{abstract}
Abstrak
Pagersari adalah dusun yang berada di Kecamatan Srumbung Magelang yang pada perencanaannya akan dikembangkan menjadi dusun wisata. Untuk mengakses dusun, diperlukan peta yang menunjukkan lokasi dan informasi yang informatif agar wisatawan dapat dengan mudah mencapai lokasi. Dusun harus memiliki sistem informasi berisi data administrasi parsial. Permasalahan yang sering terjadi adalah kurangnya pengolahan administrasi yang menyajikan data secara lengkap, akurat, dan mudah untuk di-update. Tujuan pengabdian ini adalah melakukan pembaharuan sistem informasi dusun dengan memetakan dusun yang berisi informasi mengenai data kependudukan beserta atribut lainnya sesuai kebutuhan berbasis Sistem Informasi Geografis (SIG) dan dibantu dengan menggunakan software ARCGIS lalu di-export menjadi software CarryMap. Metode pelaksanaan adalah pengumpulan data kependudukan dari kartu keluarga, pengambilan titik koordinat, dan input software ARCGIS. Hasil yang diperoleh adalah masyarakat dapat mengetahui secara rinci letak rumah warga besertakan data-data kependudukannya yang telah tersedia dalam bentuk peta online. Oleh karena itu, masyarakat dapat lebih mudah mengakses atau memperbaharui data kependudukan dusun melalui operator. Masyarakat juga dapat mencantumkan peluang usaha yang dimiliki. Dengan peta digital yang akurat, dapat mempermudah masyarakat luar untuk mencari lokasi keberadaan tempat wisata yang kelak direncanakan oleh desa sebagai desa wisata sesuai dengan potensi yang dimiliki oleh masingmasing dusun.
\end{abstract}

\begin{abstract}
Pagersari is a hamlet located in Srumbung Magelang District, which is planned to be developed into a tourist village. To access the hamlet, a map showing the location and informative information is needed so that tourists can easily reach the location. The hamlet must have an information system containing partial administrative data. The problem often occurs the lack of administrative processing that provides complete, accurate, and easy-to-update data. This service aims to update the hamlet information system by mapping the hamlet, which contains information on population data and other attributes according to the needs based on Geographical Information Systems (GIS) and assisted by using ArcGIS then exported to CarryMap software. The implementation method is collecting population data from family cards, taking coordinate points, and inputting the ARCGIS software. The results obtained are that the public can find out in detail the location of the residents' houses and the population data available in the form of an online map. Therefore, the community can more easily access or update the hamlet population data through the operator. The community can also list the business opportunities they have. With an accurate digital map, it can make it easier for the outside community to find the location of tourist attractions that the village will plan as a tourism village by the potential of each hamlet.
\end{abstract}




\section{PENDAHULUAN}

Kebutuhan mengenai penyimpanan, analisis, dan penyajian data yang berstruktur kompleks dengan jumlah besar makin mendesak seiring dengan perkembangan teknologi, khususnya komputer grafik, basis data, teknologi informasi, dan teknologi satelit inderaja (penginderaan jauh/ remote sensing) (Irwansyah, 2013, Syafriani, 2012). Struktur data kompleks tersebut mencakup jenis data spasial dan atribut. Dalam pengelolaan data yang kompleks ini, diperlukan suatu sistem informasi yang secara terintegrasi mampu mengolah baik data spasial maupun data atribut ini secara efektif dan efisien. Tidak hanya itu, sistem inipun harus mampu menjawab dengan baik pertanyaan spasial maupun atribut secara simultan. Dengan demikian, diharapkan keberadaan suatu sistem informasi yang efisien dan mampu mengelola data dengan struktur yang kompleks dan dengan jumlah yang besar ini dapat membantu dalam proses pengambilan keputusan yang tepat. Salah satu sistem yang menawarkan solusi-solusi untuk masalah ini adalah Sistem Informasi Geografis (SIG) (Harseno \& Tampubolon, 2007).

Pagersari merupakan salah satu dusun yang terletak di Desa Mranggen, Kecamatan Srumbung, Magelang yang posisinya berada di Barat Daya Gunung Merapi sehingga termasuk ke dalam daerah bahaya satu dari ancaman letusan. Tidak banyak informasi yang bisa didapatkan mengenai dusun ini, tetapi kawasan ini merupakan salah satu kawasan penghasil salak pondoh dan pertambangan pasir.

Administrasi suatu desa atau dusun sangat penting karena berisi informasi mengenai data-data kependudukan. Jika terjadi suatu bencana, akan mudah mengetahui korban jiwa dan juga kerugian yang dialami, dan data administrasi desa juga berperan penting dalam tolak ukur suatu dusun. Namun, dalam penyelenggaraannya, masih banyak dusun yang sistem administrasi desanya masih berupa cetakan biasa. Untuk peng-update-an data masih dilakukan secara manual dan membutuhkan banyak waktu (Widodo et al., 2016).

Untuk menunjang kemajuan suatu daerah, tentunya harus mempunyai sistem yang menunjang untuk mempermudah proses pelaksanaannya. Secara administrasi, Dusun Pagersari dalam pengolahan data yang berisi informasi kependudukan masih dilakukan secara manual yang membutuhkan banyak waktu, sehingga untuk memperbarui data administrasi sangat tidak efisien (Maesaroh et al., 2020). Oleh karena itu, untuk mengurangi permasalahan tersebut perlu dilakukan pembaharuan dalam sistem informasi desa salah satunya yaitu dengan memetakan daerah dusun yang di dalamnya akan berisi informasi mengenai data kependudukan, jenis usaha yang dilakukan dan lain sebagai nya sesuai kebutuhan Desa atau dusun tersebut dengan berbasis SIG dan dalam pengaplikasiannya akan dibantu dengan menggunkan software ArcGIS.

Sistem Informasi Geografis adalah sistem informasi yang berdasar pada data keruangan dan merepresentasikan objek di bumi. Dalam SIG, teknologi informasi merupakan perangkat yang membantu dalam menyimpan data, memproses data, menganalisa data, mengelola data, dan menyajikan informasi. SIG merupakan sistem yang terkomputerisasi yang membantu memelihara data tentang lingkungan dalam bidang geografis (Longley et al., 2005). Bahtiar dan Wijaya (2020) menyatakan bahwa teknologi SIG memudahkan penggunanya dalam mengelola data informasi georeferensi atau pemetaan lokasi suatu area yang terhubung dengan database. Teknologi SIG menggabungkan antara database operation seperti query dan analisis statistik dengan peta. Sistem Informasi Geografis mempunyai power untuk membuat suatu peta, integrasi informasi, visualisasi skenario, memecahkan 
masalah yang kompleks, dan mengembangkan suatu solusi efektif terhadap objek geografis yang belum pernah ada sebelumnya. Sebagai suatu tools, SIG dapat digunakan oleh individu atau organisasi seperti perguruan tinggi/sekolah, perusahaan, pemerintahan, militer, bisnis, dan masih banyak lagi (Charter \& Agtrisari, 2003).

CarryMap adalah aplikasi tambahan yang dikeluarkan oleh ESRI. CarryMap berfungsi untuk mereproduksi data yang telah dibuat dengan software ArcGIS sebagai peta mandiri tanpa aplikasi peta elektronik. Aplikasi ini dapat dibuka di desktop PC, Windows Mobile, Apple IOS dan android. Menurut Justian dan Taufik (2019), CarryMap merupakan sebuah aplikasi open-source yang digunakan untuk mendesain dan menampilkan peta sederhana hingga kompleks yang portabel sehingga mudah digunakan oleh orang awam. CarryMap dapat membuat peta portabel berbasis executable, hasil aplikasi yang dibuat merupakan file dengan ekstensi exe yang memiliki fungsi sebagai viewer dari beberapa infomasi spasial. Aplikasi CarryMap ini dapat diproteksi dengan password dan penggunaan peta dapat dibatasi hanya dalam waktu tertentu. Dengan sistem tersebut, pengelolaan data dusun lebih informatif dibandingkan dengan peta yang berbentuk JPG, PNG, PDF atau format lainnya (Ilhami et al., 2017).

Software ArcGIS sering digunakan dalam pemetaan, tetapi CarryMap masih belum terlalu familiar. Hasil akhir yang akan didapatkan adalah peta yang bisa diakses oleh siapa saja khususnya kepala dusun untuk mempermudah mencari informasi, apalagi didukung oleh lokasi yang sering mendapatkan dana CSR dari perusahaan salah satunya adalah salah satu stasiun TV swasta. Selain itu, juga pengoprasiannya yang mudah dipahami sehingga hasil akhir dari program “Pemetaan Dusun Berbasis SIG" ini berupa tampilan peta yang dilengkapi dengan atribut yaitu data-data informasi yang telah diinput sebelumnya, dan juga peng-update-an data yang mudah untuk dilakukan membuat data-data dusun tersebut selalu aktual atau update.

\section{METODOLOGI}

Kegiatan ini dilaksanakan di Dusun Pagersari, Mranggen, Kecamatan Srumbung, Magelang. terdapat 167 rumah yang menjadi titik pengambilan data. Data yang didapat Data diolah menggunakan software ArcGIS yang kemudian di-output menggunakan CarryMap yang menghasilkan peta digital berbasis CarryMap. pada kegiatan ini merupakan data kependudukan dusun.

Adapun langkah-langkah pembuatan peta digital CarryMap sebagai berikut:

1. Pertama, pegumpulan data berupa kartu keluarga adalah hal yang sangat penting karena kegiatan ini merupakan penyimpanan database pada sistem. Selanjutnya, kartu keluarga di-input kedalam Microsoft Excel, kemudian di-save menggunakan format .xls.

2. Kedua, merupakan fase lapangan, pengambilan titik koordinat menggunakan alat GPS Garmin di setiap rumah penduduk, megambil gambar kondisi eksisting rumah. Akurasi yang dihasilkan oleh GPS Garmin lebih baik jika menggunakan handphone. Pada pengambilan data ini bisa diambil kesimpulan bahwa terjadi error yakni koordinat rumah bergeser namun masih masuk dalam halaman rumah, hal ini di sebabkan oleh sulitnya jaringan yang berdampak kepada GPS (Adly, 2020).

3. Ketiga, penggambaran peta administrasi pada software ArcGIS dengan bantuan Google Maps. Cari wilayah yang akan dibuat dan pilih 4 titik yang mengelilingi daerah tersebut. Selanjutnya, catat koordinat titik tersebut dan ingat di mana saja lokasi 4 titik tersebut. 
4. Keempat, meng-input data Microsoft Excel dalam software ArcGIS. Kegiatan ini dilakukan secara hatihati untuk meminimalisasi kesalahan input. Selanjutnya, penginputan simbol titik koordinat rumah diubah menjadi simbol rumah dan nomor rumah, begitu juga dengan simbul rumah ibadah.

5. Kelima, meng-output data ArcGIS menjadi data CarryMap. Kemudian muncul kotak baru lalu klik layer titik STA yang tadi dikerjakan. Ubah templatenya menjadi template yang diinginkan. Ubah Show attachments by field dengan kolom yang berisi info foto-foto yang akan dicantumkan. Setelah semua selesai klik Extract map, lalu Start extraction. Setelah selesai, akan keluar output dengan format .cmf2 yang dapat digunakan pada CarryMap Mobile pada Android. Selanjutnya, peta dievaluasi kesesuaian data pada aplikasi CarryMap. Metode pelaksanaan dapat dilihat pada Gambar 1.

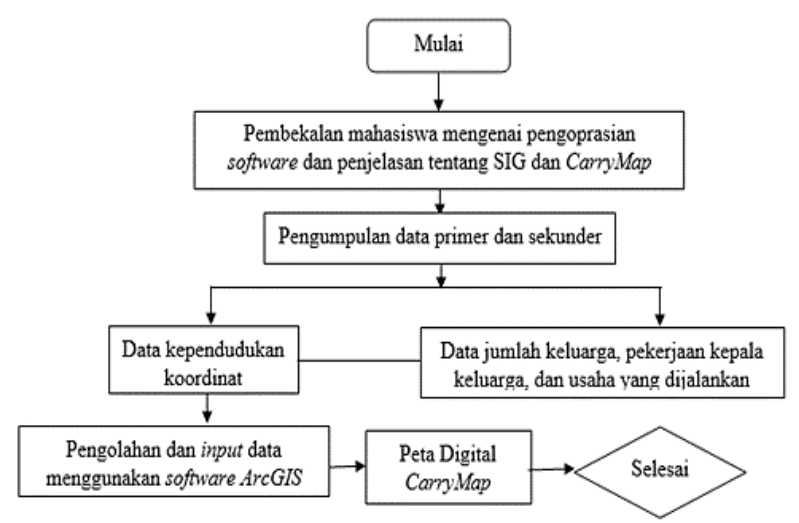

Gambar 1. Flowchart mekanisme tahapan pelaksanaan yang akan digunakan pada pemetaan Dusun Pintar Berbasis SI

Setelah database soft file terbentuk, langkah akhirnya adalah peta akan di-print dalam ukuran yang besar selanjutnya diserahkan dalam bentuk bingkai yang bagus kepada Kepala Dukuh. Dokumentasi kegiatan survei, proses pemasukan data dari penitikan rumah, serta pembuatan peta di ArcGIS dan software CarryMap disajikan pada Gambar 2 dan 3.

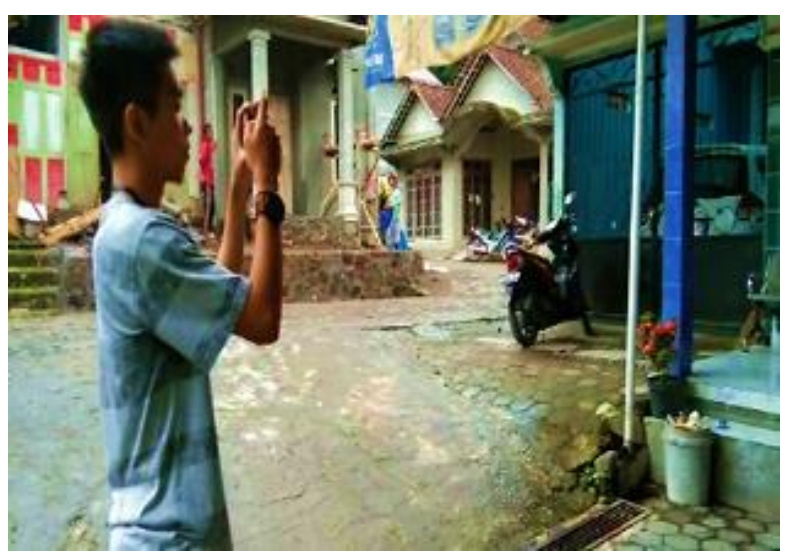

Gambar 2. Survei

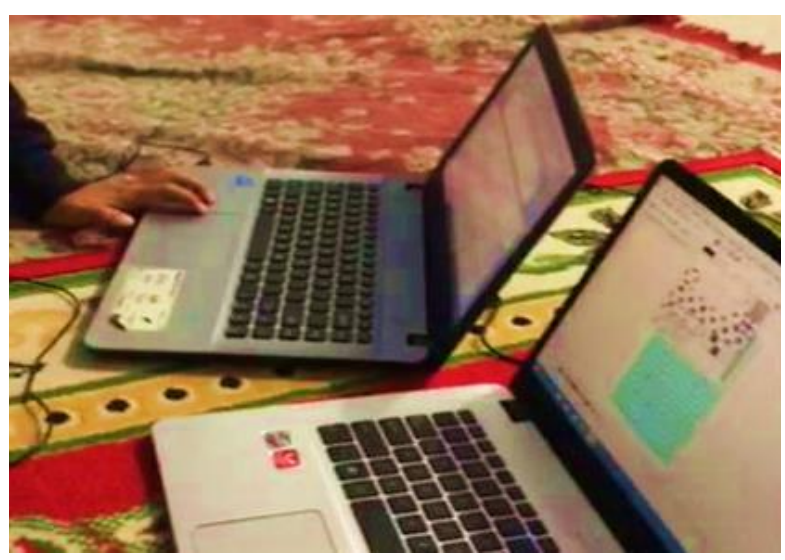

Gambar 3. Proses pemasukan data dari penitikan rumah dan sensus kependudukan warga dusun

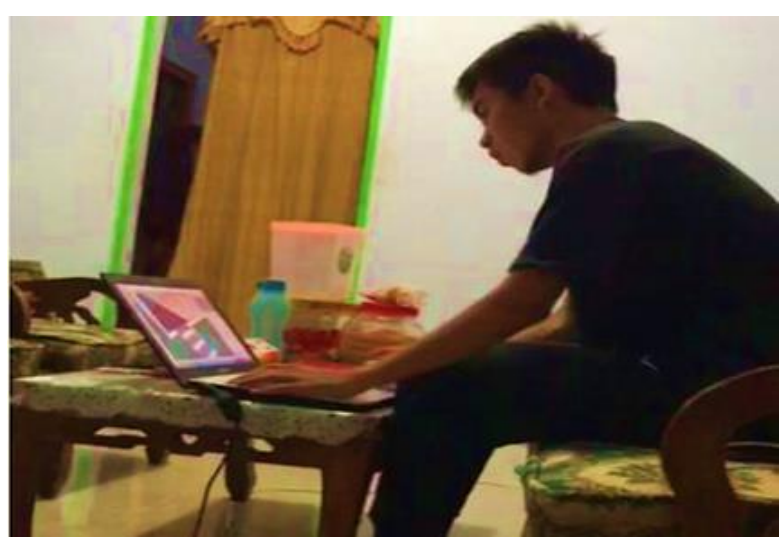

Gambar 4. Proses pembuatan peta di ArcGIS dan CarryMap

\section{HASIL DAN PEMBAHASAN}

Hasil dari pengabdian ini merupakan peta digital yang berbasis aplikasi CarryMap. Dengan CarryMap, peta berbentuk portabel ini dapat diproteksi dengan password dan penggunaan peta dapat dibatasi dalam waktu tertentu saja dan yang jelas jauh lebih informatif. 
CarryMap bisa digunakan untuk perangkat mobile yaitu Android dan IOS, tidak hanya bisa digunakan di laptop atau komputer (Moldovan et al., 2019). Cara mendapatkan aplikasi ini pun mudah yaitu dengan mengunduh aplikasi CarryMap Mobile di Playstore atau Appstore. Teknologi yang berkembang saat ini memaksa siapa pun untuk mengenal dan mampu untuk mengaplikasinya tanpa terkecuali hingga perangkat terkecil seperti dusun pun harus mampu dan siap berkembang menggunakan digital.

Tingkat perekonomian yang baik saat ini membuktikan bahwa pemuda di desa banyak yang mengenyam hingga ke perguruan tinggi termasuk Dusun Pagersi. Untuk memudahkan peng-update-an data, telah dilakukan pelatihan yang melibatkan pemuda setempat, dimulai dari pengenalan terhadap SIG, input data, hingga output peta digital seperti yang dibuat saat ini.

Data yang diinput meliputi data secara detil dalam satu buah keluarga yang terdapat pada informasi sebuah Kartu Keluarga, tetapi data ini bersifat rahasia dan output CarryMap hanya diserahkan kepada kepala dukuh saja, sedangkan data yang bisa diakses oleh masyarakat berupa database yang tidak diinput secara detil. Pada dasarnya, database bisa berupa apa saja, tetapi saat ini pengabdian yang dilakukan hanya sesuai dengan data yang ada di dalam Kartu Keluarga tersebut. Pengembangan selanjutnya dapat berupa usaha apa yang dijalani, luas rumah dan kepemilikan tanah di sekitar dusun, data pendapatan keluarga dan lain lain.

Dalam perencanaannya, Dusun Pagersari akan dikembangkan menjadi bagian dari desa wisata Mranggen, Kabupaten Magelang. Potensi wisata sudah terlihat jelas dan tinggal eksekusi dan persiapan mental masyarakat terhadap daerah wisata yang akan mereka emban. Untuk itu, peta ini menjadi tolak ukur dan dasar pemikiran yang penting sebelum dikembangkan menjadi lebih luas penggunaannya.

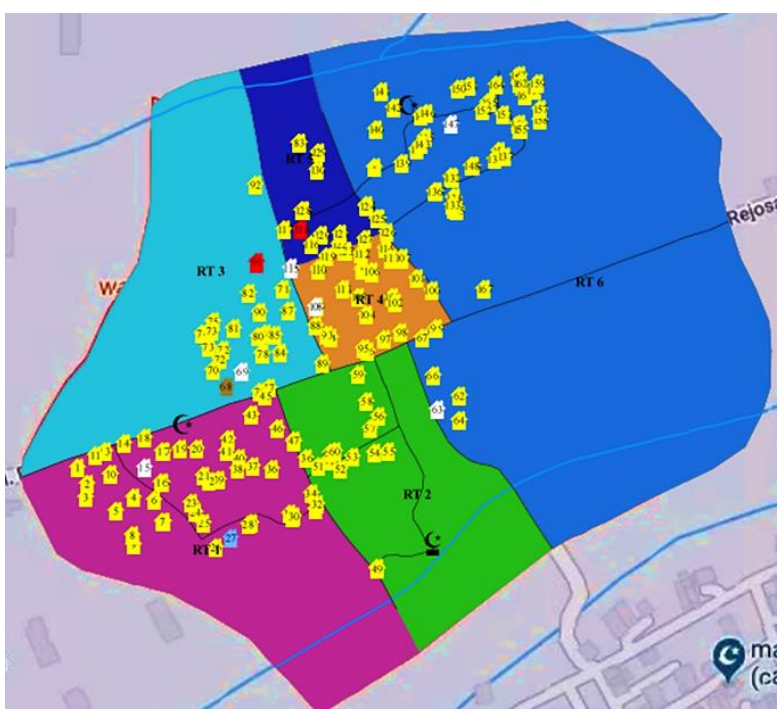

Gambar 5. Peta Digital Dusun Pagersari Menggunakan ArcGIS

Dari Gambar 5 tersebut, terdapat perbedaan warna yang sengaja dibuat, hal ini menunjukkan deliniasi tiap RT. Dusun Pagersari terpisahkan oleh ruas jalan dengan lebar \pm 4 meter dengan kondisi jalan yang baik dan sangat mendukung lokasi ini menjadi daerah wisata yang unggul nantinya. Terlihat jelas pada peta masih banyak tanah yang masih di tingkatkan lagi produktivitasnya. Salak menjadi salah satu komoditi unggulan di dusun ini, tetapi dengan teknologi dan pengembangan dusun yang telah tim pengabdi rencanakan daerah tersebut siap untuk diolah menjadi dusun pintar dan berkemajuan. Notasi yang dipilih pada peta berupa rumah dan tempat ibadah berupa masjid.

Dusun Pagersari terdiri dari 6 RT dan 167 rumah dengan kondisi ada yang lokasinya terpisah dan ada juga yang saling berdempetan. Untuk melihat data menggunkan aplikasi CarryMap, pengguna cukup memasukkan link yang telah disediakan lalu download dan otomatis akan tersimpan di handphone. Selanjutnya, akan diarahkan membuka peta tersebut dengan menggunakan aplikasi CarryMap. Setelah CarryMap terbuka, akan muncul peta seperti Gambar 5 tersebut. Selanjutnya, untuk mengetahui detail database yang dimasukkan silahkan perbesar ukuran tampilan nomor rumah dan akan 
keluar contoh seperti Gambar 6. Misalnya, RT 3 nomor

89 maka peta akan menampilkan atribut yang ada pada

kartu keluarga. Adapun link yang bisa diakses adalah:

http://bit.ly/2VWxnIB

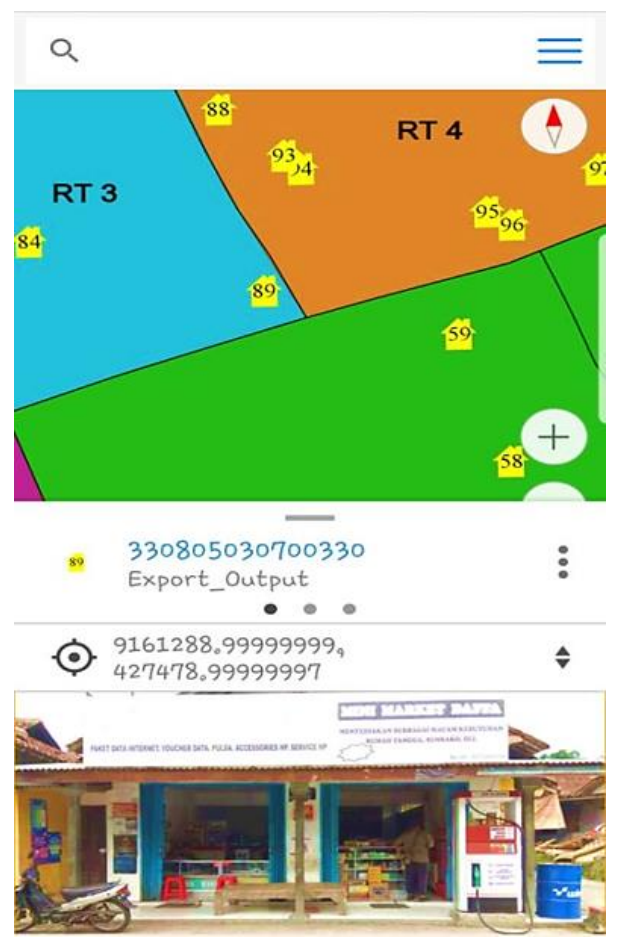

Gambar 6. Output rumah warga dan usaha yang dijalankan

\begin{tabular}{|l|l|}
\hline \multicolumn{1}{|l|}{$\begin{array}{l}\text { 330805030700330 } \\
\text { Export_Output }\end{array}$} \\
\hline O. 9161288.99999999, \\
\hline No_ & 92 \\
\hline$x$ & 427478.999999979 \\
\hline y & 9161289 \\
\hline No_KK & 330805030700330 \\
\hline No_Rumah & 89 \\
\hline Nama_Kepal & Nurudin \\
\hline RT & 3 \\
\hline RW & 9 \\
\hline Dusun & Pagersari \\
\hline Desa_Kelur & Mranggen \\
\hline Kecamatan & Srumbung \\
\hline Kabupaten & Magelang \\
\hline Anggota_Ke & Nurudin \\
\hline NIK & 3308052903790001 \\
\hline
\end{tabular}

Gambar 7. Output

\begin{tabular}{|c|c|}
\hline \multicolumn{2}{|c|}{$\begin{array}{l}\text { 30700330 } \\
\text { utput } \\
\text { - }\end{array}$} \\
\hline \multicolumn{2}{|c|}{ ๑. 9161288.99999999,} \\
\hline P_L & L \\
\hline Tempat_Lah & Mag \\
\hline Tgl_Lahir & $29 / C$ \\
\hline Agama & Islan \\
\hline J_Pekerja & Kary \\
\hline Anggota__ 1 & Ika N \\
\hline NIK1 & 3308 \\
\hline P_L1 & $\mathrm{P}$ \\
\hline Tempat_L_1 & Mag \\
\hline Tgl_Lah_1 & $23 / 0$ \\
\hline Agama1 & Islam \\
\hline J_Peker_1 & Kary: \\
\hline Anggota__2 & $\begin{array}{l}\text { Daffe } \\
\text { Putra }\end{array}$ \\
\hline NIK2 & 3308 \\
\hline
\end{tabular}

Gambar 8. Lanjutan output 1

\begin{tabular}{|l|l|}
\hline \multicolumn{1}{|c}{$\begin{array}{l}\text { 330805030700330 } \\
\text { Export_Output }\end{array}$} \\
\hline P_L2 & L161288.99999999, \\
\hline Tempat_L_2 & Magelang \\
\hline Tgl_Lah_2 & 20/01/2006 \\
\hline Agama2 & Islam \\
\hline J_Peker_2 & Belum/tidak bekerja \\
\hline Anggota_3 & Dafian Dwi Stya \\
\hline P_L3 & Putra \\
\hline Tempat_L_3 & L \\
\hline Tgl_Lah_3 & Magelang \\
\hline Agama3 & $14 / 03 / 2013$ \\
\hline J_Peker_3 & Islam \\
\hline NIK5 & Belum bekerja \\
\hline FOTO2 & 0 \\
\hline
\end{tabular}

Gambar 9. Lanjutan output 2

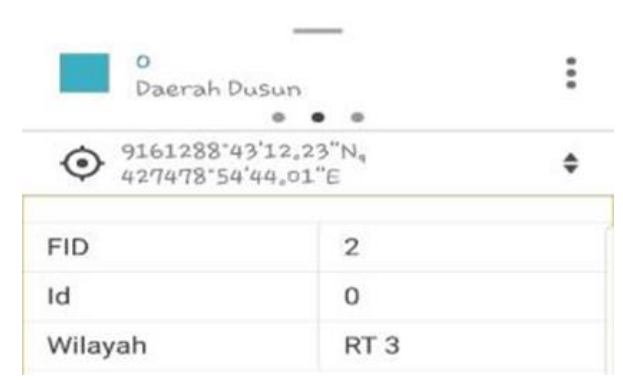

Gambar 10. Lanjutan output 3 
Gambar 6 sampai 10 menunjukkan data kependudukan pemilik nomor rumah sehingga masyarakat atau perangkat dusun lebih mudah untuk mendapatkan informasi kependudukan dari pemilik rumah tersebut. Peta digital yang bebasis CarryMap dapat mempermudah pengguna dalam mengetahui SIG yang ada di daerah peta. Hal ini tentunya akan membantu masyarakat yang ada di Dusun Pagersari dalam kemudahan penyimpanan infomasi data administrasi kependudukan dusun tersebut. Dengan perkembangan informasi teknologi saat ini hampir semua sistem informasi telah mengalihkan orientasi visualisasi dari sistem kertas menjadi sistem digital dan peta analog menjadi peta digital. Konsep peta digital yang berkembang saat ini telah mengakomodasi kebutuhan informasi yang diakses secara real time dengan metode mobile GIS (Sai et al., 2019).

\section{KESIMPULAN}

Teknologi CarryMap sangat membantu penggunaan dalam aplikasi peta digital. masyarakat dipermudah dalam pengumpulan data kependudukan dusun sehingga masyarakat dapat mengetahui secara rinci letak rumah warga besertakan data-data kependudukannya yang telah tersedia dalam bentuk peta digital yang bisa diakses dimana saja dan keunggulannya ianya bisa diakses menggunakan android dan IOS. Dalam pemanfaatan teknologi, masyarakat juga mendapat soft skill tentang cara pembuatan dan peng-update-an peta digital pada ArcGIS dan CarryMap.

\section{UCAPAN TERIMA KASIH}

Terimakasih yang sebesarnya atas pendanaan yang diberikan pleh UMY sehingga program pengabdian ini tercapai dan banyak bantuan yang bisa dikembangkan menuju dusun maju mengenal teknologi dengan baik. Selanjutnya, ucapan terimakasih ditunjukkan kepada
Dusun Pagersari Desa Mranggen, Kecamatan Srumbung, Magelang yang telah memberikan izin untuk melakukan kegiatan pengabdian masyarakat dari LP3M UMY. Ucapan terima kasih juga ditunjukkan kepada mahasiswa KKN 069 yang banyak membantu dalam kelancaran kegiatan pengabdian ini.

\section{REFERENSI}

Adly, E. 2020. Pembuatan Rumah Data Menggunakan Software ArcGISSebagai Pangkalan Informasi Dalam Bentuk Peta Digital Pokoh 1, Dlingo, Bantul, Yogyakarta. JAST: Jurnal Aplikasi Sains dan Teknologi. 4(2):75-85. https://doi.org/10.33366/jast.v4i2.1645

Bahtiar, H., Wijaya, L.K. 2020. Mobile Based Geographic Information System for mapping and data collection Towards 4.0 Industry. Journal of Physics: Conference Series. 1539:012012. https://doi.org/10.1088/17426596/1539/1/012012

Charter, D., Agtrisari, I. 2003. Desain Dan Aplikasi GIS Geographics Information System. Jakarta: Elex Media Komputindo.

Harseno, E., Tampubolon, V.I.R. 2007. Aplikasi Sistem Informasi Geografis Dalam Pemetaan Batas Administrasi, Tanah, Geologi, Penggunaan Lahan, Lereng, Daerah Istimewa Yogyakarta Dan Daerah Aliran Sungai Di Jawa Tengah Menggunakan Software. Majalah Ilmiah UKRIM. 12(1):63-80.

Illhami, M.F., Nugraha, A.L., Firdaus, H.S. 2017. Visualisasi Peta Fasilitas Penunjang Wisata Religi Kabupaten Demak Menggunakan Aplikasi Carrymap (Studi Kasus Masjid Agung Demak Dan Makam Kadilangu). Jurnal Geodesi Undip. 6(4):219-225.

Irwansyah, E. 2013. Sistem Informasi Geografis: Prinsip Dasar Dan Pengembangan Aplikasi. Digibook Yogyakarta.

Justian, W., Taufik, M. 2019. Potency Analysis of the Batik MSMES Industrial in Surabaya Using Geographic Information System. IPTEK Journal of Proceedings Series. 2:6-10. https://dx.doi.org/10.12962/j23546026.y2019 i2.5297 
Longley, P.A., Goodchild, M.F., Maguire, D.J., Rhind, D.W. 2005. Geographical Information Systems: Principles, Techniques, Management and Applications, $2^{\text {nd }}$ Edition, Abridged. New York: John Wiley \& Sons.

Maesaroh, S., Erliyani, I., Ningsih, Y.F. 2020. Aplikasi Pengolahan Data Kependudukan Industri 4.0 Berbasis Web. Journal Cerita: Creative Education of Research in Information Technology and Artificial Informatics. 6(1):95-105. https://doi.org/10.33050/cerita.v6i1.892

Moldovan, M.O., Dirja, M., Gliga, I.D., Voevod, M. 2019. Making a Digital Database Regarding Land Antierosion Organization Works and Its Dissemination Through the Carry Map Extension. Land Reclamation, Earth Observation \& Surveying, Environmental Engineering. 8:142147.

Sai, S.S., Purwanro, H., Batara, Y.D., manek, M.P.M. 2019. Mobile SIG Dalam Visualisasi Peta Rencana Detail Tata Ruang Kota Dengan Pemotretan Udara Tanpa Awak. Jurnal Poros Teknik. 11(1):23-30. https://doi.org/10.31961/porosteknik.v11i1. 800

Syafriani, D. 2012. Pembuatan Sistem Informasi Geografis Pelayanan Umum Di Kecamatan Nanggalo. Jurnal Momentum. 13(2):1-11.

Widodo, T.H., Nurhayati, O.D., Windasari, I.P. 2016. Pembuatan Aplikasi Sensus Penduduk Untuk Desa Wulunggunung. Jurnal teknologi dan Sistem Komputer. 4(1):9-16. https://doi.org/10.14710/jtsiskom.4.1.2016.916 